\title{
CHALLENGES IN LINKING PRECLINICAL ANTI-MICROBIAL RESEARCH STRATEGIES WITH CLINICAL OUTCOMES FOR DEVICE-ASSOCIATED INFECTIONS
}

\author{
T.F. Moriarty ${ }^{1, *}$, D.W. Grainger ${ }^{2}$ and R.G. Richards ${ }^{1}$ \\ ${ }^{1} \mathrm{AO}$ Research Institute Davos, AO Foundation, Davos, Switzerland \\ ${ }^{2}$ Departments of Pharmaceutics and Pharmaceutical Chemistry, and of Bioengineering University of Utah, \\ Salt Lake City, UT 84112 USA
}

\begin{abstract}
Infections related to implanted medical devices have become a significant health care issue in recent decades. Increasing numbers of medical devices are in use, often in an aging population, and these devices are implanted against a background of increasing antibiotic-resistant bacterial populations. Progressively more antibiotic resistant infections, requiring ever more refined treatment options, are therefore predicted to emerge with greater frequency in the coming decades. Improvements in the prevention, diagnosis and treatment of these deviceassociated infections will remain priority targets both for clinicians and the translational research community charged with addressing these challenges.

Preclinical strategies, predictive of ultimate clinical efficacy, should serve as a control point for effective translation of new technologies to clinical applications. The development of new anti-infective medical devices requires a validated preclinical testing protocol; however, reliable validation of experimental and preclinical antimicrobial methodologies currently suffers from a variety of technical limitations. These include the lack of agreement or standardisation of experimental protocols, a general lack of correlation between in vitro and in vivo preclinical results and lack of validation between in vivo preclinical implant infection models and clinical (human) results. Device-associated infections pose additional challenges to practicing clinicians concerning diagnosis and treatment, both of which are complicated by the biofilms formed on the medical device.

The critical challenges facing both preclinical research and clinical laboratories in improving both diagnosis and treatment of medical device-associated infections are the focus of this review.
\end{abstract}

Keywords: Medical implants, infection strategy, antibiotic resistance, in vitro-in vivo correlations, clinical translational research.

*Address for correspondence:

T. F. Moriarty

AO Research Institute Davos,

AO Foundation,

Clavadelerstrasse 8

Davos Platz, CH7270

Switzerland

Telephone Number: +41814142397

FAX Number: +41814142288

E-mail: fintan.moriarty@aofoundation.org

\section{Introduction and Overview of Device-Associated Infection}

Bacterial colonisation of medical devices, leading to infection of the adjacent tissues, is a widely recognised, serious complication for a significant minority of patients receiving such implants (Busscher et al., 2012). Certain aspects of implant-related infections distinguish their cause, effects and possible therapeutic options from normal surgical site infections: low inocula required for infection propagation, wide varieties of pathogens involved, difficulty in eradication using antibiotic therapies alone, and possible immunosuppressive environments induced by implant foreign body reactions. It has been shown numerous times that the mere presence of an implant consistently reduces the number of bacteria required to cause an infection by up to four or more orders of magnitude (Table 1) (James and MacLeod, 1961; Zimmerli et al., 1982; Widmer et al., 1990; Poelstra et al., 2000; Poelstra et al., 2002), a central concept first conclusively shown in human subjects in the 1950s (Elek and Conen, 1957). The importance of the implant is further highlighted by the fact that treatment of these biofilm infections may not be successful unless the implant, and thus the biofilm, is removed (Berkes et al., 2010). Once established, device infections prompt device malfunctions, patient morbidity, substantial risk of mortality, and continuing medical and/ or surgical interventions, often at substantial costs to both patients and payers (Busscher et al., 2012).

It is increasingly evident that, despite sterilisation, nearly all medical devices and/or the surgical field are contaminated peri-operatively prior to or during implantation procedures (Alexander et al., 2013). This is a logical consequence of the fact that the operating suite is not sterile: surgical equipment (e.g., handles, lights, keyboards, floors, walls) is often contaminated (Stone et al., 2002; Pittet et al., 2004; Allo and Tedesco, 2005; Howard and Hanssen, 2007). Similarly, surgical suite doors open and disrupt the laminar air flow in the operating room from 19-50 times per hour across surgical specialties (Lynch et al., 2009) and on average 60 times during a single total hip arthroplasty, or 135 times for a revision arthroplasty (Panahi et al., 2012). Additionally, both the patient and attending surgical staff are not sterile: bacteria/fungal sourcing is common from dust, skin, respiratory particles, hair, and clothing (Trampuz and Widmer, 2004). Furthermore, nearly a third of uncovered surgical trays are contaminated after a few hours of surgery (Dalstrom et al., 2008). Given estimated bacterial seeding rates for a standard operating theatre during a surgical 
Table 1. Overview of in vivo studies demonstrating reductions of bacterial numbers required to cause infections in the presence of a foreign body versus no foreign body.

\begin{tabular}{|c|c|c|c|c|c|}
\hline \multirow[b]{2}{*}{ Study } & \multirow[b]{2}{*}{ Host } & \multirow{2}{*}{$\begin{array}{c}\text { Foreign Body } \\
\text { (FB) }\end{array}$} & \multicolumn{2}{|c|}{ Minimum Infectious dose (CFU) } & \multirow[b]{2}{*}{ Pathogen } \\
\hline & & & No FB & With FB & \\
\hline Elek 1957 (2) & Human & Sutures & $5 \times 10^{6}$ & $3 \times 10^{2}$ & S. aureus \\
\hline James 1961 (3) & Mouse & Sutures & $10^{6}$ & $<10^{3}$ & S. aureus \\
\hline Widmer 1988 (5) & Guinea Pig & Cages & $>10^{7}$ & $10^{3}$ & S. epidermidis \\
\hline Zimmerli 1982(6) & Guinea Pig & Cages & $>10^{7}$ & $10^{2}$ & S. aureus \\
\hline Poelstra $2000(7)$ & Rabbit & K-wire & $>10^{4}$ & 500 & MRSA \\
\hline Poelstra 2002 (4) & Mouse & Mesh & $>10^{6}$ & $10^{4}$ & P. aeruginosa \\
\hline
\end{tabular}

procedure of $\sim 270$ bacteria $/ \mathrm{cm}^{2} / \mathrm{h}$, (Fitzgerald, 1979) there are plenty of opportunities for contamination in wound sites. Whether modern air filtration and ultra-violet (UV) field sterilisation protocols reduce this pathogen-seeding threat has been recently disputed by studies that show no statistically significant differences in infection rates in ultra-sophisticated versus conventional surgical suites (Uckay et al., 2013).

A significant proportion of implant infections are therefore believed to be acquired during normal, modern surgical procedures (Hanssen et al., 1997). This is supported by the consistent success of vigilant infection surveillance programs and infection prevention measures focused on the operating theatre, and by evidence matching pathogenic strains both from surgeons' fingers (Uckay et al., 2010) and from patients nasal cavities (von Eiff et al., 2001; Perl et al., 2002) with infecting organisms. Despite consistent pathogen exposure and high seeding and contamination rates, implant surgeries are actually remarkably successful: infection rates for most medical devices are less than $10 \%$ and sometimes less than $1 \%$ (Uckay et al., 2010). The consistently high contamination rate in comparison with a low, if variable, infection rate, reflect combinations of yet unknown factors that must coincide to successfully propagate infections in certain patient and implant types.

Once established, an infection associated with an implanted medical device presents numerous challenges precluding successful treatment outcomes. A primary reason why implant-associated infections are particularly challenging to treat is the formation of bacterial biofilms on implant surfaces and adjacent tissue sites (Gristina et al., 1988). Once established, these biofilms are generally refractory to antibiotic treatments (Høiby et al., 2010). Hence, expensive surgical intervention is often required to remove the colonised device and debride the surrounding tissue to achieve a successful treatment outcome. The enormous socioeconomic costs and recent refusal by insurance companies to pay for so-called "preventable" complications (www.medicaid.gov in the USA; (Stone et al., 2010)) including common catheter-associated blood stream and urinary tract infections, has driven substantial amounts of research and development recently into diagnosing, preventing and treating medical deviceassociated infections.

At certain critical points, interventions may significantly influence infection risk. These include: patient preoperative preparations; stringent infection control procedures in hospital wards; appropriate and timely antibiotic selection and prophylaxis; optimal surgical skill and technique; judicious use of antimicrobial-loaded devices; and careful patient monitoring and follow-up to ensure timely and rapid diagnosis of those relatively rare cases where device infection does develop (Alexander et al., 2013; Uckay et al., 2013). The scientific community, in collaboration with industrial and clinical partners, have the responsibility to provide sufficient basic understanding of the pathological processes occurring when bacteria colonise and eventually cause an infection, and how and when to best intervene in these situations. The challenges and current barriers associated with efficient transformation of this understanding from preclinical laboratories into novel, effective, commercial antimicrobial patient interventions have been comprehensively reviewed recently (Busscher et al., 2012; Grainger et al., 2013).

The introduction of next-generation antibiotic agents has declined in past decades due to limited market incentives, given numerous agents already approved and relatively modest profit incentives for pharmaceutical companies that develop them (Livermore, 2011). Overreliance on and clinical abuse of the current repertoire of conventional antibiotics has produced a major threat to current medical treatment of infection: the emergence of multiple antibiotic-resistant bacteria such as Methicillin Resistant Staphylococcus aureus (MRSA), vancomycin resistant enterococci and multi-resistant Acinetobacter baumannii. In contrast to an apparent lack of industrial interest in developing new antimicrobials, development of antimicrobial-loaded medical devices has been increasing (Brooks et al., 2013). This includes increasing antimicrobial additions to medical devices: e.g., multiple manufacturers now provide numerous antimicrobial catheters and endotracheal tubes (Darouiche, 2013; Kollef, 2013). Antimicrobial-releasing devices are now also increasingly available in orthopaedic surgery, currently focusing on high-risk cases such as open tibial fractures (Fuchs et al., 2011), or revision of prosthetic joints (Hardes et al., 2007). As prospective clinical trials for these devices in the current regulatory climate are frequently economically impossible (Busscher et al., 2012; Grainger et al., 2013), the retrospective clinical efficacy of such devices must be followed closely in the coming years as their use becomes more widespread and sufficient clinical follow-up data emerge. Full and careful reporting of the clinical impact of these types of implants will facilitate forecasting of possible roles that this strategy could play 
in clinical routine and will ultimately dictate clinical acceptance.

While thousands of "academic" concepts for antimicrobial implants are published annually, most never make it even to human prototyping stages (Grainger et al., 2013). The pathway to product regulatory approval and commercialisation is expensive and time-consuming, requiring commitment and some predictive capabilities of in vivo performance for process risk management. The standard product development path for any anti-infective device concept includes extensive preclinical in vitro and in vivo testing that determines device safety and efficacy prior to further clinical trials in human patients. When applied to addressing medical device infections, however, the pathway lacks clear rationale and scientific rigor. The reality we now face is that critical links between in vitro and in vivo preclinical testing are neither as correlative nor predictive of clinical efficacy as may have been expected (Grainger et al., 2013). Similarly, preclinical in vivo testing does not necessarily correlate with clinical outcomes and performance (Busscher et al., 2012; Proctor, 2012; Grainger et al., 2013). Why these important discrepancies exist is not yet clear. However, their multifactorial basis, including the non-standard designs of in vitro assays; the diverse varieties of preclinical animal models chosen; the relative robustness of animal immune anti-infection competence in comparison to human systems; the different microorganisms selected and inability to assay certain key features of actual human infection susceptibility including patient co-morbidities and inter-individual variability, all limit the accuracy, predictability and validity of technology translation beyond preclinical testing (Table 2) (Busscher et al., 2012; Grainger et al., 2013).

\section{Challenges in Studying Device-Associated Infection in vitro}

In vitro assessment of infection risk is not a required preclinical test for most medical devices. In the case of anti-infective devices, however, preclinical testing of their antimicrobial efficacy in various guises is generally performed to determine the extent and duration of pathogen killing for a number of relevant bacterial species. The exact configuration of the assessment is not usually standardised. However, some International Organization for Standardization (ISO) guidelines exists for testing materials (e.g., ISO 22196). These guidelines are often surpassed in terms of the quantity and variety of tests performed by independent academic laboratories as seen in the published literature (Katsikogianni and Missirlis, 2004; Moriarty et al., 2011). Unfortunately, many controversies surround the (1) performance of these tests, (2) lack of standardisation of many aspects of experimental design and variables, and (3) relevance to the in vivo situation, and this lack of consensus is not often addressed. Validated, realistic assessment protocols recognising specific critical assay features, including standards and their predictive utility would represent a significant step forward.

\section{Bacterial adhesion, growth and biofilm formation on biomaterials}

The specific affinity of a given bacterial cell for an implant material or surrounding tissue is among the first steps known to influence microbial contamination leading to the development of infection. Bacterial adhesion represents an area of considerable past and current interest in basic understanding of the colonisation process, and also for the development of improved anti-adhesive materials. The process of device colonisation and tissue infection develops in a stage-wise manner: from preconditioning of the biomaterial with host matrix proteins, followed by initial microbe adhesion, growth and ultimately microcolony and, in select cases, biofilm formation on the surface of the material (Fig. 1). Bacteria react and respond to adhesion within what has recently been described as three different regimes of adhesion forces (Busscher and van der Mei, 2012). Each and all of these regimes and steps in the process are amenable to in vitro investigation and much research has been performed on various implant materials and model surfaces (for examples, see references (Hudson et al., 1999; Katsikogianni and Missirlis, 2004;

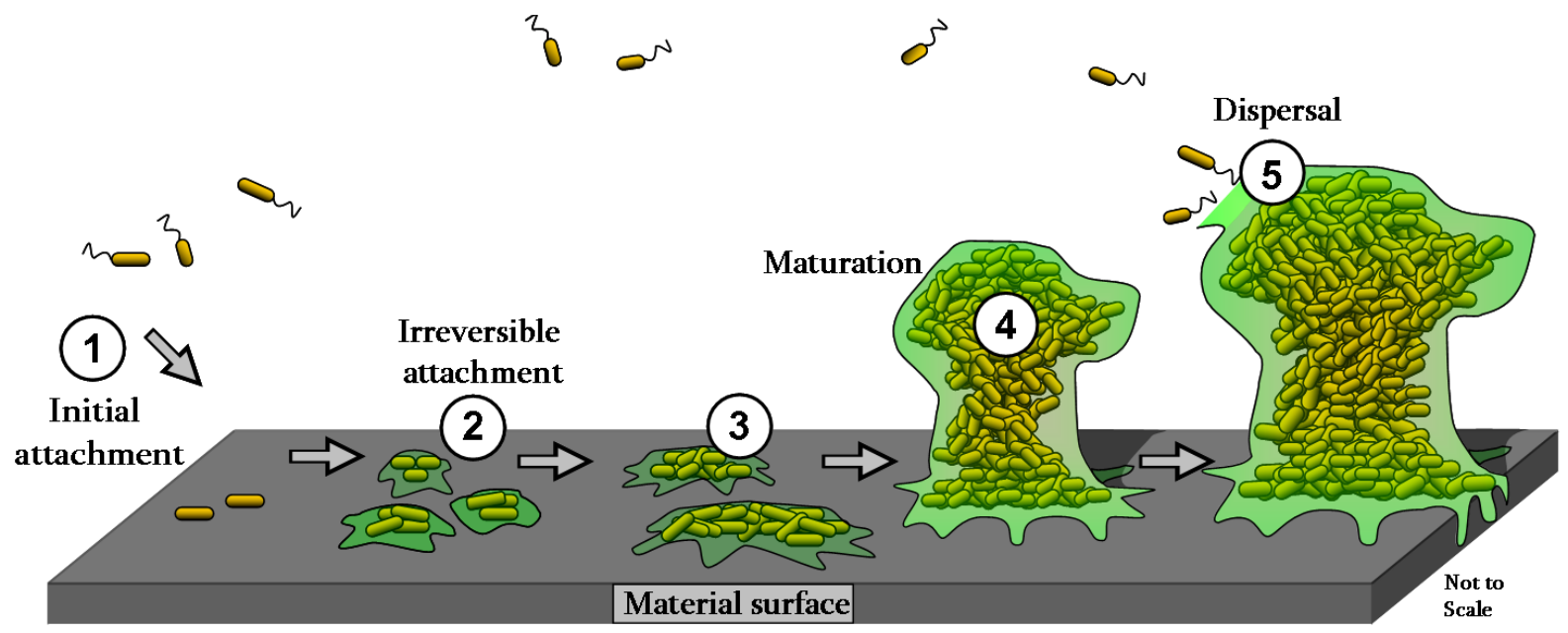

Fig. 1. Overview of bacterial adhesion and biofilm formation (Moriarty et al., 2011). Each step, from initial adhesion to biofilm formation is amenable to in vitro evaluation. Generating clinically relevant in vitro results remains a challenge. (Figure reproduced by permission). 
Table 2. Summary of challenges in preclinical testing related to implant infections.

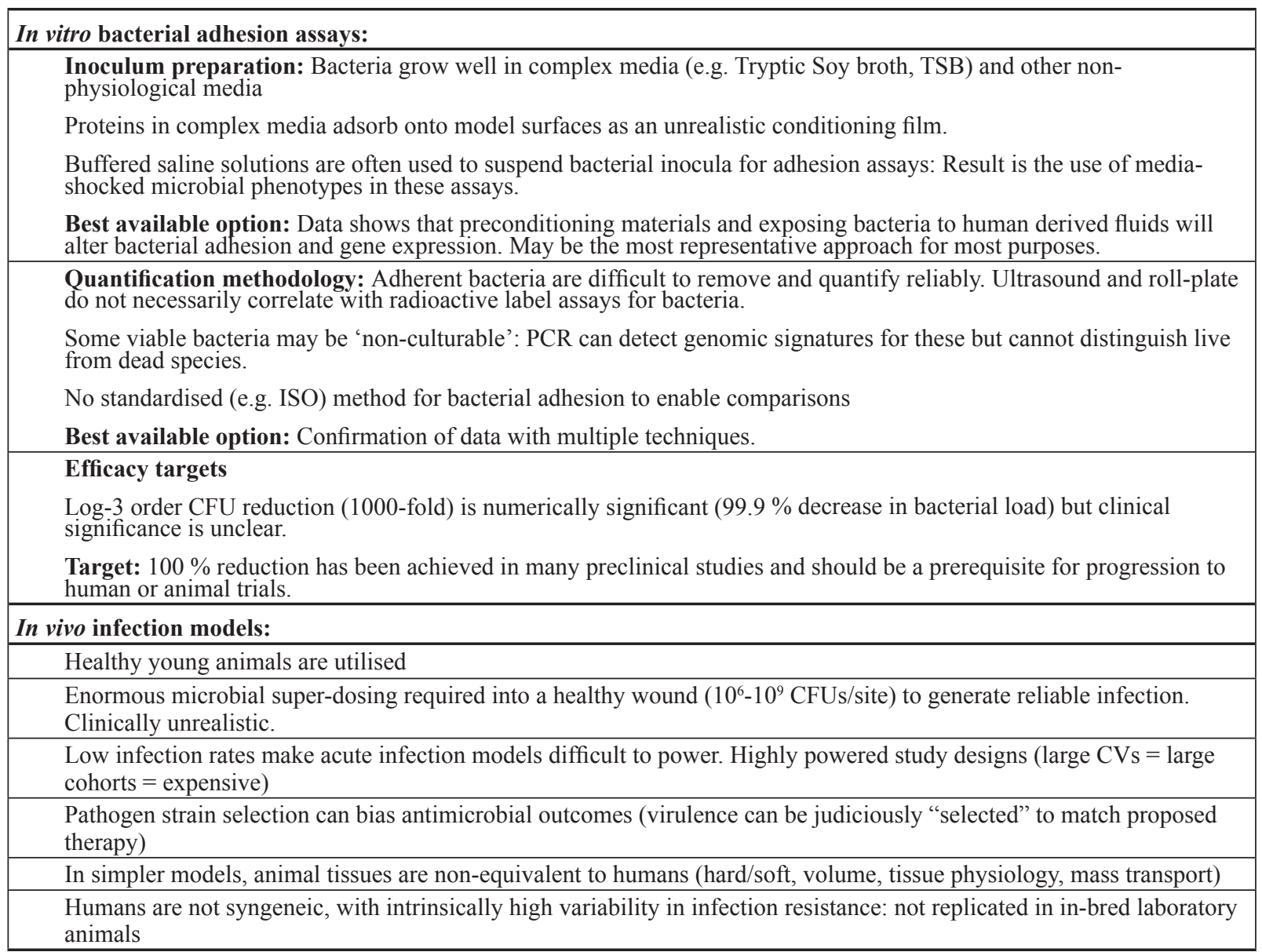

Montanaro et al., 2008; Moriarty et al., 2011). In this regard, bacterial adhesion may in fact be variously represented as an adhesion force, resistance or ease of detachment or a combination of these. In order to generate data that contribute new insights to colonisation, careful attention should be paid to these specific measurements and how they are designed, described and defined. Detailed review of many methods and definitions is outside the scope of this review, however, further information may be found in numerous topical reviews (Gottenbos et al., 1999; Katsikogianni and Missirlis, 2004).

Broadly speaking, bacteria adhesion to biomaterials is mediated in one of two ways: either directly to the bare biomaterial or indirectly by a poorly defined and highly variable protein conditioning film adsorbed on the biomaterial. The adherent protein layer on the biomaterial surface (Kasemo and Lausmaa, 1994) affords contaminating bacteria a more specific adhesion mechanism using highly evolved microbial surface receptors (adhesins) (Chagnot et al., 2013). Specific adhesion may be investigated in vitro by preconditioning biomaterial samples in either defined or complex proteinaceous solutions. However, the precise chemical and physical constitution of the conditioning layer on implants in vivo is impossible to replicate in vitro, or even to validate for accuracy. Furthermore, it is difficult to separate the relative contribution of nonspecific and specific mechanisms of bacterial adhesion to actual infection propagation either in vitro or in vivo.
Ultimately, the inability of a material to completely and reliably eliminate all bacterial adhesion events is a device performance issue. Material-based reduction of adhesion by $98 \%$ may seem a numerical in vitro success. However, the clinical impact must be proven and frequently this in vitro microbial adhesion resistance does not translate to clinical infection resistance. The typical claims for in vitro efficacy, with a 3 log-order reduction (i.e., $99.9 \%$ reduction) in surface-adherent colony forming units (CFUs) after a $24 \mathrm{~h}$ assay, fail to consider many of the dynamics of the in vivo situation. Bacterial doubling times of $20 \mathrm{~min}$ in exponential growth phases mean that the remaining few CFUs of adhering bacteria can re-populate any surface with many new colonies in a few hours. They are also capable of rapidly up-regulating genes to remodel their adhesion profiles to produce new armadas of surface attachment mechanisms, and drug efflux pumps to address antimicrobial threats. Additionally, adherent bacteria are intrinsically more resistant to antibiotic assault and cellular phagocytosis, particularly over time as they evolve into biofilms.

A more recent innovation in in vitro investigations of bacterial-material interactions has involved co-culture systems whereby bacterial contamination and host (eukaryotic) cell interactions with implanted biomaterials are assessed in the same in vitro system. This design has been termed the "race for the surface" (Gristina et al., 1988). By modelling this scenario and including both 
prokaryotic pathogens and eukaryotic cells within a single in vitro test bed, this process may be a significant step towards more clinically relevant assays (Subbiahdoss et al., 2009). These new systems have shown, for example, that bacterial interactions with fibroblasts, osteoblasts and macrophages may be influenced by the substrate biomaterial in vitro (Subbiahdoss et al., 2010a; Subbiahdoss et al., 2010b; Subbiahdoss et al., 2011). One example outcome from these studies has been a realisation that bacterial toxins, such as those produced by $S$. aureus and Pseudomonas aeruginosa can effectively and rapidly induce eukaryotic cell death in co-cultures, effectively eliminating eukaryotes in competition for surface adhesion (i.e., bacteria win the "race"). In contrast, less virulent microorganisms, such as $S$. epidermidis, compete with viable host cells for surface adherence. In this system, therefore, host cell responses to local toxin production near biomaterials surfaces and resultant eukaryotic cell death replicate in some ways certain aspects of the clinical situation, whereby $S$. epidermidis causes slower, subacute infections, characterised by a more indolent type of infection, in the absence of significant toxin production, and thus less local cell death. One important aspect of these co-culture systems is adapting both the pathogen strain and cell type to a common media supporting growth and correct phenotype for both species. As bacterial growth kinetics greatly outpace mammalian cell division rates, inoculum numbers and media composition can be adjusted to slow bacterial proliferation to level the playing field with the disadvantaged mammalian cells. Identifying optimal growth conditions for both prokaryotes and eukaryotes represents an area that requires development before coculture assays become a useful addition to the field.

While research into the process of bacterial adhesion to materials, and interference in this process by material design strategies, may potentially provide routes to generating more contamination-resistant, bacterialrepellent biomaterials, few adhesion-resistant innovations have translated to improved antimicrobial clinical performance (Busscher et al., 2012).

\section{Bacterial inoculum preparation for antimicrobial assessments}

Most standard in vitro assays involve bacteria cultured in a nutrient-rich non-physiological medium, typically a tryptic soy broth (TSB), general nutrient broth, or similar growth media with a complex non-mammalian protein content. In a bacterial adhesion assay, these broth proteins adsorb onto test surfaces, influencing bacterial binding, thereby rendering the results less than fully applicable to any clinical situation. Therefore, in many studies, cultured bacteria are first washed in a buffered salt "minimal" medium generally lacking proteins and then deposited onto the test material in a similar buffered salt solution. This reduces the chance of culture medium protein interference with the result. This scenario however, effectively 'shocks' bacteria in culture without effective media adaptation. The physiological response of non-adapted bacteria is certainly affected in terms of growth rate, transcription profiles (metabolism-, adhesin-, toxin-production related genes, for example) and phenotype. The effect of such culture media shock on bacterial adhesion assays, or any other in vitro assay, has not been fully established to date, though likely to be significant. Similarly, serum-adapted pathogens, capable of surviving serum-based cultures, are rarely used though this would certainly be a step forward toward improved relevance. Numerous examples have shown that growth in ex vivo culture conditions can alter gene expression or adhesive ability differently than in vitro conditions (Wiltshire and Foster, 2001; Massey et al., 2002; Yarwood et al., 2002). For example, growth in used peritoneal dialysate effectively saturated $S$. aureus adhesins and reduced bacterial adhesion to fibronectin and fibrinogen versus controls grown in a conventional Todd-Hewitt broth (Massey et al., 2002).

\section{Bacterial species and strain selection}

Biomaterial-associated infections may be caused by a wide range of bacteria, either singly or in polymicrobial infections. However, the majority of isolates from a given device class are from comparatively few species. For example, within orthopaedic devices, the staphylococci account for a majority of isolates cultured using conventional means (Tunney et al., 1999; Trampuz et al., 2007; Schafer et al., 2008), and in catheter-associated urinary tract infections, the staphylococci are again prevalent alongside Gram negatives such as E. coli and $P$. aeruginosa (Matsukawa et al., 2005). Hence, antimicrobial preclinical device testing should include a range of bacterial species commonly reported to cause infections associated with the particular device type.

Strain selection within a pathogen species is just as important. The clinical significance or relevance of the entire preclinical investigative phase can be profoundly influenced both by the choice of bacterial species and strain within that species. Considering the significant variations commonly found within bacterial populations, selecting a test strain representative of a significant fraction of the pathogenic strains causing clinical infections is a crucial aspect in preclinical studies (Campoccia et al., 2008). For example, $S$. aureus is commonly isolated from infections related with several different medical devices. From a microbiological perspective, $S$. aureus virulence is often classified by toxic, adhesive or evasive parameters, in addition to antibiotic resistance (Rooijakkers et al., 2005; Clarke and Foster, 2006; Otto, 2010). Since whole genome sequencing of bacteria has become much more affordable in recent years, it has been realised that the make-up of different $S$. aureus strains may vary by up to $20 \%$ (Lindsay and Holden, 2006). Furthermore, gene expression, particularly expression of numerous virulence factors, is under the control of global regulators that are themselves highly variable between strains of $S$. aureus (Rogasch et al., 2006). It is, therefore, highly likely that within a potential population of strains available for preclinical testing, significant differences between virulence potential and regulation are observed. Clinical strains of $S$. aureus with differing repertoires of virulence genes have already been associated with differing clinical progression. For example, the USA 300 MRSA strains are known to be highly toxic and capable of causing significant disease even in healthy people (Que et al., 2005; Deleo et al., 2010; 
Otto, 2010). In contrast, less virulent but more antibioticresistant hospital-acquired MRSA clones are common in the U.K. and Ireland and prevalent in chronic infections in susceptible hosts (Collins et al., 2010; Rudkin et al., 2012). Therefore, the selection and use of antimicrobial strains in preclinical testing must consider the source of the strain, its repertoire of virulence factors, and how this correlates with the clinical application and disease in question. In vitro antimicrobial efficacy in a given strategy is profoundly impacted by strain selection: biased success can result from selecting weak microbial strains not relevant to clinical pathology.

Another important issue is the fact that many clinical infections, particularly chronic open wounds (Fazli et al., 2009) and many musculoskeletal infections (e.g., diabetic foot infections) are polymicrobial infections (James et al., 2008; Peters et al., 2012). Numerous in vitro and in vivo studies have shown that interspecies bacterial interactions directly impact bacterial virulence factor production and disease severity in vivo (Mastropaolo et al., 2005; Sun et al., 2008; Dalton et al., 2011). Fundamental mechanisms underpinning these effects remain to be elucidated. However, the known mechanisms that underpin bacteria:bacteria communication include quorum sensing, synergistic immunomodulation, augmented virulence factor production and direct contact-dependent mechanisms. One study investigating $S$. aureus and $P$. aeruginosa polymicrobial infection in an implant-related spinal model in the rat found that these two species displayed a complex pathogenic synergy (Hendricks et al., 2001). Low numbers of $P$. aeruginosa and $S$. aureus caused more infections than expected for either bacterium alone at an equivalent bacterial inoculum. Confirmatory studies have shown that Gram-negative infections do in fact potentiate Grampositive infections (and vice versa) (Duan et al., 2003; Dalton et al., 2011). For example, it has been shown in a murine model that $P$. aeruginosa detects the presence of Gram-positive peptidoglycan and responds by increased production of virulence factors in vivo (Korgaonkar et al., 2013). Peptidoglycan production by $S$. aureus was found to increase $P$. aeruginosa infection, and reduce numbers of Gram-positive bacteria in both a Drosophila and a murine chronic wound model (Korgaonkar et al., 2013). The reduction in Gram-positive bacterial numbers was attributed to an increase in toxin production affecting the Gram-positive bacterial population.

\section{Bio-optical imaging and bioluminescent strains in device-associated infection models}

Bio-optical imaging of either bioluminescence or fluorescence signals from engineered pathogens, antibiotics and biomarkers, is emerging as an invaluable tool in device associated infection models. Bioluminescent, lightproducing $S$. aureus strains are commercially available and increasingly used for in vivo and in vitro infection imaging research since they can be directly imaged in tissue or implants. The $S$. aureus strain Xen29 is derived from the pleural fluid clinical isolate ATCC 1260017, strain Xen36 is derived from the bacteraemia isolate ATCC 49525 (Pribaz et al., 2012) and Xen40 is derived from the highly reported, virulent osteomyelitis clinical isolate, UAMS-1
(Elasri et al., 2002). Xen29 and Xen40 showed similar concentration-dependent increases in bioluminescent signals that peaked on day 3 in a mouse model of infection and then decreased to a steady-state level that was 2- to 4-fold above background levels from 14 to 42 days (Pribaz et al., 2012). In contrast, Xen36 had higher concentrationdependent increases in bioluminescent signals that peaked on day 3 then decreased to a steady-state level that was 8- to 10 -fold above background levels from 14 to 42 days (Pribaz et al., 2012). Higher optical emission signals observed for Xen36 compared with Xen29 or Xen40 in these models was likely due to the placement of the bioluminescent construct in a stable bacterial plasmid in Xen36 (Pribaz et al., 2012) whereas Xen29 and Xen40 contain one copy of the bioluminescent construct placed in the bacterial chromosome (Kadurugamuwa et al., 2003; Pribaz et al., 2012). These models suggest that these $S$. aureus bioluminescent pathogens have certain phenotypic and pathogenic traits useful for in vitro and in vivo infection assays. Further validation using side-by-side comparisons with clinical isolates will be required to assert more equivalence.

In addition, fluorescent marker molecules have been validated for use in in vivo imaging of experimental models of infection (Sjollema et al., 2010; Daghighi et al., 2014) and cadaveric trials in humans have shown promise for fluorescently labelled vancomycin (van Oosten et al., 2013). A recent study that combined bioluminescent bacterial strains with fluorescent observation of inflammatory process (Daghighi et al., 2014) highlights the possibilities of these techniques, which are certain to become important tools in the research arena, though potentially also in the clinical diagnosis of infection.

\section{Assessing antimicrobial efficacy and elution}

The development of any antimicrobial-loaded device will also require evaluation and optimisation of antimicrobial release kinetics and local dosing efficacy and pharmacology. The optimal antimicrobial release profile has not been clearly validated for any clinical situation. Reliable pathogen killing is the desired performance yet how this outcome is best and reliably linked to antibiotic release in vivo is not proven. Typically, most biomaterials release antimicrobial fractionally with an initial substantial burst release, lasting from minutes to one or more days and $40-70 \%$ of total drug load. Such a release profile may be suitable for short-term devices (e.g., endotracheal tubes), or those at elevated risk of infection at time of implantation (e.g., intramedullary nailing after open fracture). Antibiotic-loaded bone cement clinically used in the treatment of osteomyelitis is characterised by a substantial burst (Neut et al., 2010). An alternative release profile that is regularly pursued is an extended or controlled release pattern that attempts to minimise drug burst. Typically, this may involve controlled erosion or degradation of matrix surface layers, gradually releasing antimicrobial beneath, or chemical modification of the drug to change the release from the surrounding material.

The preclinical assessment of antimicrobial-loaded devices is unfortunately fraught with challenges in determining clinical efficacy. Clearly, release kinetics of 
the antimicrobial from the carrier are a function of matrix size, shape, and porosity. In vitro testing of convenient coupons or discs may therefore not reflect release from a large coating spread over a complex device, such as a prosthetic joint for example. Furthermore, the antimicrobial release may be significantly influenced by the composition, temperature and volume of fluid surrounding the test material. Higher release concentrations may be achieved by immersing large release matrix in a small volume of release fluid, which is an artificial situation not representative of any realistic in vivo situation. In a time course experiment, results may be affected if each sample point completely replaces all the surrounding release fluid versus small samples taken and replaced with an equal volume. Generally, infinite sink conditions are recommended for assays to provide clear understanding of the release kinetics in vitro. However, how this relates to the in vivo situation is unclear. Above all other aspects discussed presently, it would be valuable and achievable to produce guidelines on the conditions required for in vitro testing of biomaterials releasing antimicrobial drugs. Such guidelines are currently not available.

\section{Challenges in Studying Device-Associated Infection in vivo}

\section{Requirements for in vivo studies}

Preclinical in vivo testing for safety and efficacy testing of potential anti-infective interventions is required to petition regulatory bodies for possible human use. Since in vitro tests are incapable of replicating the complex host response to bacteria, tissue trauma and placement of a medical device, such preclinical determinations in vivo are required. Nonetheless, precise experimental paths needed to address regulatory concerns for antimicrobial devices in humans are frequently unclear and continuously evolving worldwide. This uncertainty and the costs associated with pursuit of any statistically validated in vivo tests have proven to be barriers for innovation (Busscher et al., 2012, Grainger et al., 2013). Despite specific regulatory considerations for combination devices, primary mode of action as a medical device must be shown to be unaffected by secondary delivery of antimicrobial agent or the antimicrobial property. Co-predicate claims are possible to assert in regulatory filings (i.e., for a precedent approved similar implanted device and a precedent approved drug in the same therapeutic context) as the basis for a combination device 510k Federal Drug Administration (F.D.A.) application in the USA, but the success of this strategy as the basis for regulatory approval are unknown. Additionally, ostensible clinical trial designs are generally the same as for a new medical device, regardless of this designation, meaning that trials will be costly and extensive, limiting commercial enthusiasm for their pursuit in the face of shifting, uncertain regulatory demands. In some cases, the regulatory pathway for antimicrobial strategies (even for devices) has been designated to be as an investigational new drug, requiring more extensive testing and clinical assessments, and trial costs, frequently a "no- go" for further testing and development on a commercial basis.

In moving antimicrobial strategies to in vivo testing, the critical factor contributing to infection risk is the underlying trauma or pathology that requires surgical intervention. In the case of soft and hard tissue damage caused by trauma, the local tissue effects may also include cellular necrosis, devascularisation, hypoxia, haematoma, oedema and increased intra-compartmental pressure (Gristina et al., 1991; Guillou, 1993; Wichmann et al., 1996). The associated compromised vascular perfusion can lead to reduced humeral and cellular immune competences at the site of injury (Hoch et al., 1993). These immunological deficits can then lead to infection susceptibility independent of whether or not the wound is open or closed (Gustilo and Anderson, 1976; Krettek, 1998) and whether soft (Kalicke et al., 2003) and/or hard tissues are traumatised (Wichmann et al., 1996). Many of these risk factors for device-associated infection are clearly not amenable to in vitro investigation. Thus, in vivo models have proven indispensable in the preclinical testing of anti-infective interventional strategies. A comprehensive review of in vivo implant infection model pros and cons is not within the scope of the present review; however, numerous reviews are available on this topic (An and Friedman, 1998; Calabro et al., 2013).

\section{Basic limitations of in vivo models}

Many infection risk factors are patient-specific, such as immune status, tissue compromise and co-morbidities. Unfortunately, many of these human factors are also challenging to introduce into in vivo studies (Table 2). In contrast to diverse co-morbidities and varying immune competences of human patients, the overwhelming majority of in vivo studies use young, healthy and often syngeneic animals, despite the fact that young healthy patients are the minority in device-associated infection. For example, syngeneic in-bred rodents are intrinsically resistant to infection, resulting in difficulty in reliably creating even short-lasting acute infections. To produce infections, these models often require either deliberate addition of a sclerosing agent or extremely high doses of bacterial inoculum (Norden, 1970). Sclerosing agents are a particularly questionable addition in bone infection studies as they may influence bone loss independent of infection status. Reports have shown that infected animals displayed similar radiographic changes to uninfected animals in receipt of sclerosing agents (Scheman et al., 1941).

Similarly, super-dosing of high bacterial inocula into these animals is an equally unrealistic situation for modelling all device-associated infections, with the possible exception of open traumatic wounds. The numbers of bacteria found in operating room exposures (e.g., $10^{2} \mathrm{CFUs}$ ) are many orders of magnitude lower than the mega-doses (i.e., $10^{5}-10^{9} \mathrm{CFUs}$ ) of bacteria inoculated into healthy test animals. Alone, the addition of very large numbers of bacteria will elicit a large immune response, regardless of whether an infection develops or not. The requirement for such high doses to produce infection is a clear indication that the animal model used is highly 
resistant to infection. This is a significant limitation in terms of replicating the clinical situation where infections are considered to arise from much lower inocula.

One interesting study investigated the incidence of infection in experimental animals included in tissue engineering research studies. It appeared that these constructs, even though they have maintained a seeded, viable eukaryotic cell population within the construct, appear to have infection rates equivalent to human patients receiving an implant (Kuijer et al., 2007). The "opportunism" present in human surgical infections is thus replicated in these examples and represents an accurate, though non-practical (ethical and economical) model for opportunistic and subclinical infections.

\section{Testing against immunologically naive animals}

For the predominant pathogens causing device-associated infections, such as $S$. epidermidis and $S$. aureus, preclinical studies are regularly performed in specific pathogenfree animals. As such, the hosts have been bred with particular attention to ensure that the animals do not retain any infectious pathogens that may contribute to anomalous results. Furthermore, these species do not carry endogenous strains of these microorganisms under normal circumstances, and are unlikely to have significant transcutaneous inoculation of these particular species. The use of disease-free animals is clearly an important factor to ensure that healthy animals are used in research studies: however, it should be contrasted with the clinical reality whereby the normal patient populations are certain to have experienced numerous minor temporary septicaemia or tissue abrasions, exposing these patients to staphylococcal antigens for many years. The patient therefore will have a complex bank of immune "memory" to staphylococci. The contrast with the test animal is therefore significant, where the inoculation of bacteria directly into the wound is the first immunological exposure to this species. Such stark differences may be particularly important for investigations of passive and active immunisation strategies against pathogens, the development of sub-acute infection models, and the impressive ability of some species to seemingly repel enormous "super-dose" inocula in infection models.

\section{Microbial virulence in vitro, ex vivo and in vivo}

Numerous bacterial virulence factors are differentially expressed depending upon environmental conditions. These include adhesins, toxins, immune evasive molecules and even global regulatory loci (Chan and Foster, 1998; Lammers et al., 2000; Vriesema et al., 2000; Goerke et al., 2001). MSCRAMMs are a family of staphylococcal adhesins known to play crucial roles in early stages of infection by facilitating adhesion to host tissues or the surfaces of implants after preconditioning with host proteins. S. aureus MSCRAMM expression was demonstrated to fluctuate with growth phase (McAleese et al., 2001), growth culture environment (Massey et al., 2002) or intracellular survival within neutrophils (Garzoni et al., 2007). Data have also shown that MSCRAMM gene expression may be altered during in vivo growth that cannot be replicated by in vitro or ex vivo conditions (Sellman et al., 2008). For example, it has been shown

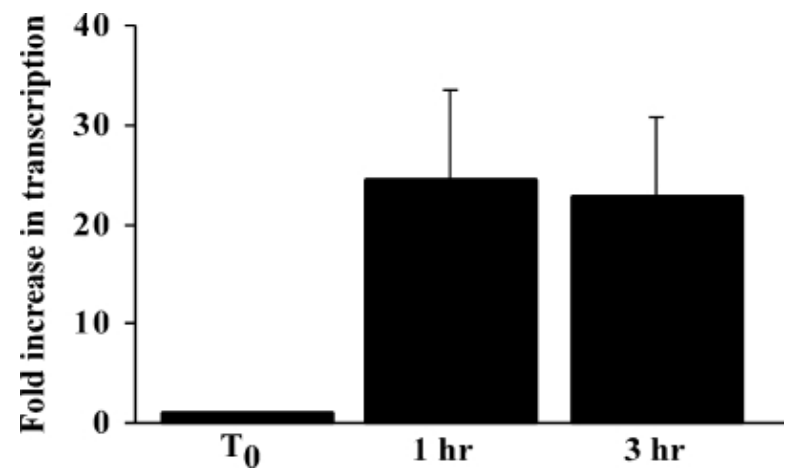

Fig. 2. Illustration of the difference between in vitro and in vivo conditions of virulence factor expression in $S$. epidermidis. sdrG is a surface-associated fibrinogen binding protein present in most strains of Staphylococcus epidermidis. In vitro $\left(\mathrm{T}_{0}\right)$ expression is low, but results show an increased transcript level $1 \mathrm{~h}$ following a shift from growth in nutrient broth to growth in the bloodstream of a mouse (Sellman et al., 2008). (Figure reproduced by permission).

that bacterial surface adhesins of $S$. epidermidis were expressed after $30 \mathrm{~min}$ in a murine model (Figure 2). However, neither growth in TSB nor growth in a serumsupplemented growth medium could induce expression of the particular MSCARAMM in question (SdrG, a surface-associated fibrinogen binding protein). A similar study investigated $S$. aureus transcriptional responses to either log phase growth, stationary phase growth, or growth in vivo over a period 0.5 to $6 \mathrm{~h}$ in the murine lung. As many as 1000 gene transcripts were shown to either increase or decrease after even 30 min growth in vivo, in comparison with either laboratory condition (Chaffin et al., 2012). Affected transcripts included nutrient acquisition and virulence factor expression and regulation, including phenol soluble modulins and alpha toxin (Chaffin et al., 2012). Similar type studies have also shown transcriptional changes between in vitro cultured $S$. aureus and in vivo models of endocarditis (Xiong et al., 2006) and cystic fibrosis lungs (Goerke and Wolz, 2004), highlighting that global transcriptional changes that occur in $S$. aureus upon exposure to an in vivo environment are not replicated by in vitro conditions. In a model specifically focused on medical device-associated infection, Goerke et al. showed that regulation of alpha toxin production was altered after growth in a guinea pig host compared with in vitro growth (Goerke et al., 2001). Furthermore, it appeared that alpha toxin and coagulase were closely linked to sae (global regulator) expression in vivo (Goerke et al., 2005), which contrasts with the in vitro situation where the agr regulator appears to play a more prominent role.

Certain "in vivo" niches have also been reported with regards to biofilm formation. In one example, two strains of $S$. aureus that differentially express the biofilm-forming polysaccharide intercellular adhesin (PIA) in vitro and in vivo were studied. S. aureus strain RN6390 produced PIA in vitro (only after $48 \mathrm{~h}$ anaerobic growth), whereas $S$. aureus Newman did not produce PIA under any in vitro 
conditions. However, after growth in a subcutaneous tissue cage model in murine and guinea pig hosts, both $S$. aureus strains produced PIA late in the infection course, indicating an in vivo biomaterial associated infection specific response not detected by conventional in vitro growth (Fluckiger et $a l ., 2005)$. Similar data also show that biofilm isolates taken from human patients with cystic fibrosis display significant differential gene expression in vivo in comparison with in vitro cultured biofilms (Goerke et al., 2000).

\section{Host species-specific virulence}

The relative importance of virulence factors and immune evasion factors may be significantly variable between different host species (Holtfreter et al., 2010). Speciesspecific activity of bacterial toxins has recently emerged as a potential confounding factor in preclinical in vivo trials of at least some virulence factors (Loffler et al., 2010). The S. aureus exotoxin Panton-Valentine leukocidin (PVL) is found in a majority of MRSA strains that cause CA-MRSA infections, such as necrotising pneumonia and skin and soft tissue infections (Lina et al., 1999; Gillet et al., 2002). In numerous mouse studies and in vitro studies using murine cells, PVL was not found to significantly activate or kill murine neutrophils (Voyich et al., 2006; Bubeck et al., 2007). However, later discoveries in vitro showed that PVL did activate and kill human and rabbit neutrophils, but was inactive against mouse or monkey neutrophils (Fig. 3) (Loffler et al., 2010). This specificity for rabbit neutrophils is somewhat corroborated by preclinical studies in vivo whereby rabbits were in fact found to display differential response to infection with PVL positive and corresponding PVL negative mutants (Diep et al., 2008; Cremieux et al., 2009; Lipinska et al., 2011), which was undetected in the murine models. The reason for the species-specific sensitivity to this toxin is unknown, but varying receptors or signal transduction pathways between species are likely to be responsible. This highlights the importance of species selection, since some animals do not necessarily correctly replicate $S$. aureus diseases in humans.

\section{Preclinical success does not preclude clinical failure}

The most prominent examples of anti-infective strategies that passed preclinical test phases yet failed in early clinical trials are numerous staphylococcal vaccines developed over the past decades (Botelho-Nevers et al., 2013). A wide range of active staphylococcal vaccine targets have been selected on the basis of preclinical animals studies, and efficacy has been variable, though often promising. Unfortunately, all have failed in clinical trials to date. For example, a vaccine targeting the iron-sequestering protein, IsdB, showed promising results in preclinical in vitro and in vivo tests (Kuklin et al., 2006; Brown et al., 2009). Unfortunately, clinical studies could not support the use of this vaccine in cardiothoracic patients (Fowler et al., 2013). Possible reasons for the failure of this and similar vaccines are discussed elsewhere (Scully et al., 2014), though precisely why the discrepancy exists remains largely unexplained. Similarly, preclinical murine studies indicated that a tumour necrosis factor (TNF)- $\alpha$ receptor therapy showed efficacy in a mouse endotoxemia model (Mohler et al., 1993), yet human clinical trials proved less successful (Fisher et al., 1996). On-going uncertainty in how antimicrobial strategies fail to translate from preclinical to clinical efficacy and the considerable costs of failure in translation have led to risk-aversion among many biomedical device commercialization efforts.

\section{Challenges Posed by Device-Associated Infections to the Clinical Laboratory}

\section{Suitability of PK/PD principles in device-associated biofilm infections}

Clinical therapies for all bacterial infectious diseases are based upon administration of antibiotics. The selection of the particular antimicrobial regimen and dosage used are based on a combination of laboratory test results, empirical selection and basic pharmacokinetic and pharmacodynamic principles. The minimum inhibitory concentration (MIC) is a familiar anti-microbiological parameter related to the minimum concentration of a particular antimicrobial agent in solution required to inhibit growth of a particular microorganism under defined, planktonic conditions. In theory, the MIC is used to estimate the likelihood of in vivo efficacy as it is correlated with dosing, potency and pharmacokinetics in humans and usual dosage regimens. Careful attention to pharmacodynamic principles has been shown to correlate with the treatment of some infectious diseases such as hospital-acquired pneumonia (Kim et al., 2009), however, this is not necessarily true for all infections (Smith et al., 2003). For example, biofilm growing bacteria do not retain the MIC values of their planktonic counterparts and, similarly, the growth phase of the bacterium may affect the MIC, or MBC (minimum bactericidal concentration) of some antibiotics (Kim and Anthony, 1981). The discrepancy between such laboratory results (MIC) and biofilm susceptibility has been conclusively shown for cystic fibrosis (Moriarty et $a l ., 2007)$ and orthopaedic device isolates when grown as biofilm (Molina-Manso et al., 2013). This phenomenon is believed to hold true for all bacterial biofilms, at least those of medical concern. The lack of in vitro:in vivo dosing correlation for treating biofilm-related diseases has spurred development of "biofilm inhibitory concentrations" (BIC) or minimum biofilm eliminating concentration (MBEC) assays (Sepandj et al., 2004). Typically, the BIC/MBEC is usually significantly higher than the MIC, as would be expected. Nevertheless, attempts have been made to tailor antibiotic dosage regimens to the BIC/MBEC rather than the MIC. In cystic fibrosis, where biofilm infections are present on and near the lining of the alveoli in the lungs of affected patients, a trend for reduced bacterial load upon completion of the MBEC-led antibiotic regimen (Keays et al., 2009) was found in early studies, however, later studies could not identify a significant effect (Moskowitz et al., 2011).

Lack of efficacy of single antibiotic agents has led to the use of antibiotic combination therapies for many infectious diseases. Antibiotic combinations are potentially synergistic and investigations have sought to answer whether antibiotic therapy tailored to synergistic combinations display improved treatment outcomes. 
Fig. 3. The cytolytic effect of purified S. aureus virulence factors on neutrophils from different species (Loffler et al., 2010). Species differences in cytolytic activity highlight the importance of species selection in in vivo studies. (Figure reproduced by permission).
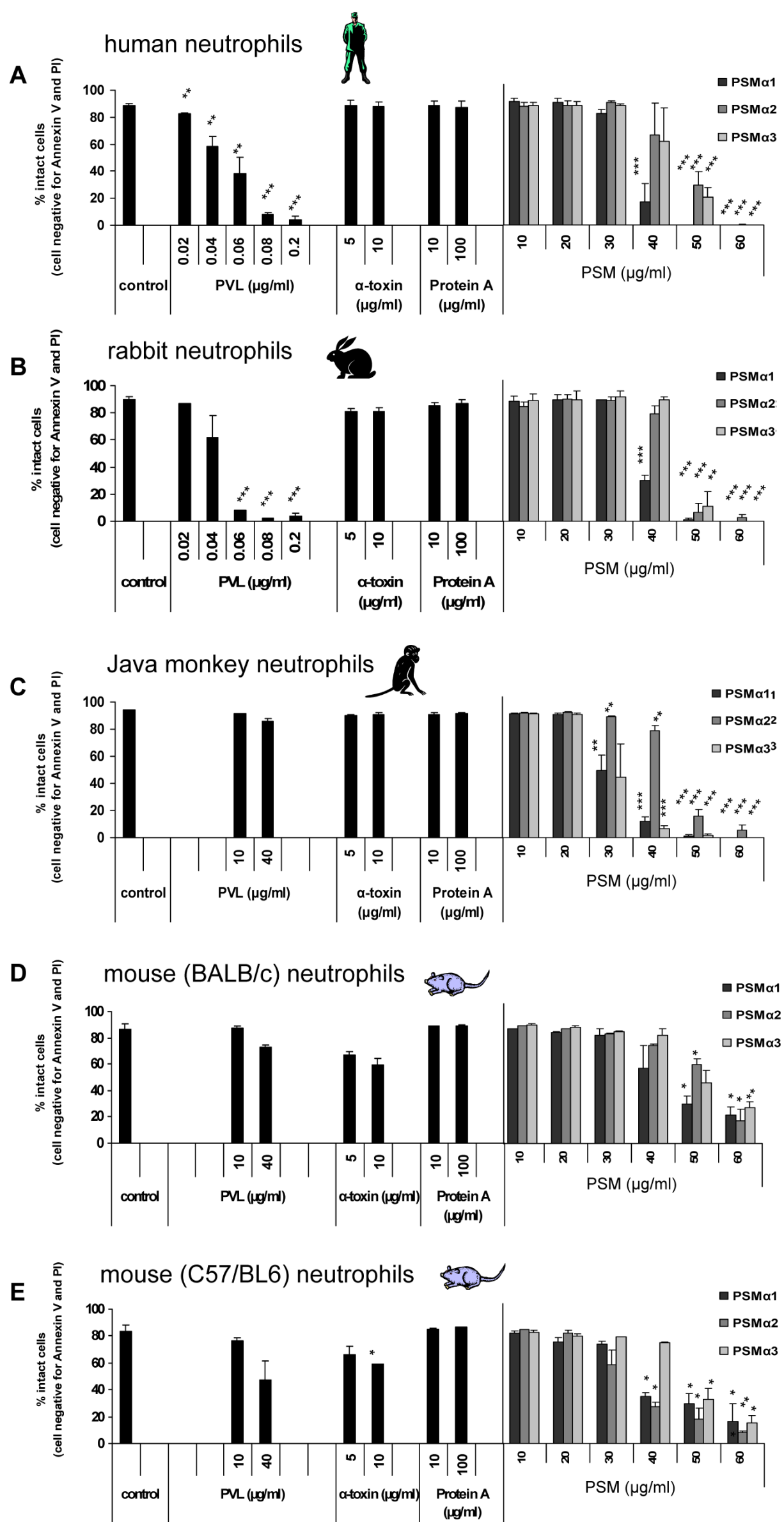
Unfortunately again, despite many claims to efficacious antimicrobial synergy for combination drugs, clinical antimicrobial efficacy of antibiotic combinations did not improve treatment outcomes over and above empiric therapy for cystic fibrosis patients (Aaron et al., 2005), although some prophylactic effect against septicaemia in transplant patients was observed (Haja et al., 2012). In contrast, antibiotic combinations have been shown to offer protection against infection when present on catheters without any observed increase in antibiotic resistance (Ramos et al., 2011; Brooks et al., 2013).

One interesting approach to developing an in vitro assessment of antibiotic efficacy against biofilm and mimicking the normal in vivo fluctuations in local antibiotic concentrations was reported by Widmer et al. (Widmer et al., 1990) Their strategy involved growing bacterial biofilms on small glass beads and exposing them to fluctuating antibiotic concentrations predicted based on normal human drug pharmacokinetics. The authors were able to identify antibiotic combinations that could be shown to result in eradication of biofilm in vitro (Widmer et al., 1990). Replicating these treatment scenarios in the guinea pig exhibited a correlation between the regimens found to work in vitro with clinical outcomes in vivo. This approach has not been extensively repeated, despite demonstrated utility in clinical situations, and warrants further investigation and utilisation.

\section{The detection of biofilm infections in the clinical microbiology laboratory}

The clinical microbiology laboratory is tasked with assessing the presence, identity and antibiotic resistance pattern of bacteria in clinical specimens. In the realm of medical device-associated infections, a slowly emerging realisation is that these infections are frequently biofilm infections and require specific biofilm-detection techniques. Not all infections produce biofilms, but biofilms are increasingly implicated in difficult-to-treat implant-associated infections (Busscher et al., 2012). Numerous studies have shown that sampling from the explanted device, by targeting the biofilm on the surface, increases the detection rate of bacteria in comparison with directly sampling tissues (Tunney et al., 1999; Trampuz et al., 2007). The method of choice for detecting implant infections is surgical explant sonication, with subclinical or quiescent infections sometimes detected by this method when infection was not suspected by the treating physician (Tunney et al., 1999; Trampuz et al., 2007). Similarly, it has been shown that by extending bacterial culture times, the detection rate of numerous pathogens may be increased (Schafer et al., 2008), particularly slow-growing, fastidious pathogens such as Propionibacterium acnes. In addition, to enable detection of pathogens in the clinical laboratory, each microorganism causing the infection must obviously be capable of growth in the culture media regularly in use in clinical microbiology laboratories. Broadly nonselective and enrichment broths and agars, such as blood agar and thioglycolate broth, are commonly used. The most commonly isolated microbes from implant-related osteomyelitis, $S$. aureus and $S$. epidermidis, are eminently culturable in standard growth media. Unfortunately, an estimated $90 \%$ of bacterial species are not culturable by conventional nutrient media or may be in a viable but non-culturable state (Oliver, 2010). Thus, a significant proportion of bacterial species, at least in theory, may be missed due to inappropriate detection techniques. This problem is further compounded by the realisation that bacteria growing within a biofilm may also be nonculturable, even less fastidious microbes such as $S$. aureus (Palmer et al., 2011), through mechanisms that to date remain unexplained.

Through the use of more sophisticated detection techniques, the true prevalence of bacterial infection in medical device-associated infection may be emerging (Palmer et al., 2011). For example, by combining biofilm sonication from explanted orthopaedic implants and nonculture polymerase chain reaction (PCR)-based techniques, the detection of bacterial contamination around failed (septic and "aseptic") implants has been shown to be increased (Tunney et al., 1999). Similar data has been replicated numerous times since, even in the absence of PCR data, further highlighting the clinical relevance of sonication (Trampuz et al., 2007). More recently, the IBIS system (Ecker et al., 2008), a mass spectrometry-based technology developed for rapid detection of potential bioterrorism-related microbes, was also found to be capable of identifying the bacteria present in wound tissue with greater sensitivity than culture or PCR (Palmer et al., 2011; Howe et al., 2013). Using this technique, it has been shown that large numbers of a diverse array of microbes may colonise tissues adjacent to orthopaedic implants, and which due either to biofilm formation or fastidious growth requirements, do not grow in laboratory conditions. The clinical implications of such work are potentially very significant, though it remains to be seen how practices in the clinical microbiology laboratory may be affected, since such equipment is out of the range of most hospital laboratories from a cost and operational perspective. It should also be recognised that many of the molecular techniques described provide confirmation only of the presence of bacterial DNA, and not proof of a viable bacterium. There is significant risk that an infection that has been cleared may be DNA-positive for dead bacteria, which is a significant uncertainty. Potentially, centralised reference laboratories could serve to provide definitive diagnosis of bacterial contamination of tissues in all cases of hardware failure or removal, whether an infection is clinically suspected or not. Nevertheless, it is clear that current conventional bacteriological practices are likely to be significantly under-reporting clinical infections. This subsequently leads to under-reporting in the literature, further exacerbating the lack of evidence to support research into the methods and assessing their outcomes.

\section{Summary and Conclusions}

With increasing prevalence of multi-drug resistant bacteria in the hospital setting, clinicians are already faced with treating device-associated infections using a diminishing arsenal of anti-infective tools. To survive regulatory scrutiny to enter the market as a product, let 
alone achieve a clinically measureable impact, new antiinfective interventions must be subjected to preclinical test regimens that robustly and consistently provide clinically relevant evaluation. Neither in vitro nor in vivo testing currently provides a satisfactory level of proof to reliably predict efficacy for each subsequent step in the product development process. Presently, it seems that current testing protocols are not fit as a reliable screen prior to clinical implementation. In order to achieve the clinical goals of both reducing incidence and improving treatment of device-associated infections, improved validation, testing, and interpretation standards must be set. Consensus is unavailable and currently no formal scientific or medical bodies are vested in achieving this ideal. Cross-disciplinary research networks aimed at providing fundamental targets for preclinical testing and based on representative clinical demands shall be required to advance towards this goal. Currently, the research output on the topic suffers from notable lack of consensus, vast disparity in testing protocols and limited correlations with clinical realities.

\section{Acknowledgements}

The authors are grateful to Dr. A. Brooks (Utah, USA) for technical comments and to continued insights from Profs. H. van der Mei and H.J. Busscher (Groningen, The Netherlands) for leading expertise and insights into these infection modelling problems.

\section{References}

Aaron SD, Vandemheen KL, Ferris W, Fergusson D, Tullis E, Haase D, Berthiaume Y, Brown N, Wilcox P, Yozghatlian V, Bye P, Bell S, Chan F, Rose B, Jeanneret A, Stephenson A, Noseworthy M, Freitag A, Paterson N, Doucette S, Harbour C, Ruel M, MacDonald N (2005) Combination antibiotic susceptibility testing to treat exacerbations of cystic fibrosis associated with multiresistant bacteria: a randomised, double-blind, controlled clinical trial. Lancet 366: 463-471.

Alexander JW, Van SH, Vanoss K, Hooker EA, Edwards MJ (2013) Surveillance of bacterial colonization in operating rooms. Surg Infect (Larchmt) 14: 345-351.

Allo MD, Tedesco M (2005) Operating room management: operative suite considerations, infection control. Surg Clin North Am 85: 1291-1297, xii.

An YH, Friedman RJ (1998) Animal models of orthopedic implant infection. J Invest Surg 11: 139-146.

Berkes M, Obremskey WT, Scannell B, Ellington JK, Hymes RA, Bosse M, Southeast Fracture C (2010) Maintenance of hardware after early postoperative infection following fracture internal fixation. J Bone Joint Surg Am 92: 823-828.

Botelho-Nevers E, Verhoeven P, Paul S, Grattard F, Pozzetto B, Berthelot P, Lucht F (2013) Staphylococcal vaccine development: review of past failures and plea for a future evaluation of vaccine efficacy not only on staphylococcal infections but also on mucosal carriage. Expert Rev Vaccines 12: 1249-1259.
Brooks B, Brooks A, Grainger D (2013)Antimicrobial medical devices in preclinical development and clinical use. In: Biomaterials Associated Infection (Moriarty TF, Zaat SAJ, Busscher HJ, eds), Springer New York, pp 307354.

Brown M, Kowalski R, Zorman J, Wang XM, Towne V, Zhao Q, Secore S, Finnefrock AC, Ebert T, Pancari G, Isett K, Zhang Y, Anderson AS, Montgomery D, Cope L, McNeely T (2009) Selection and characterization of murine monoclonal antibodies to Staphylococcus aureus ironregulated surface determinant B with functional activity in vitro and in vivo. Clin Vaccine Immunol 16: 1095-1104.

Bubeck WJ, Bae T, Otto M, Deleo FR, Schneewind O (2007) Poring over pores: alpha-hemolysin and PantonValentine leukocidin in Staphylococcus aureus pneumonia. Nat Med 13: 1405-1406.

Busscher HJ, van der Mei HC (2012) How do bacteria know they are on a surface and regulate their response to an adhering state? PLoS Pathog 8: e1002440.

Busscher HJ, van der Mei HC, Subbiahdoss G, Jutte PC, van den Dungen JJ, Zaat SA, Schultz MJ, Grainger DW (2012) Biomaterial-associated infection: locating the finish line in the race for the surface. Sci Transl Med 4: 153 rv110.

Calabro L, Lutton C, Din A, Richards RG, Moriarty TF (2013)Animal models of orthopedic implant-related infection. In: Biomaterials Associated Infection (Moriarty TF, Zaat SAJ, Busscher HJ, eds), Springer New York, pp 273-304.

Campoccia D, Montanaro L, Moriarty TF, Richards RG, Ravaioli S, Arciola CR (2008) The selection of appropriate bacterial strains in preclinical evaluation of infectionresistant biomaterials. Int J Artif Organs 31: 841-847.

Chaffin DO, Taylor D, Skerrett SJ, Rubens CE (2012) Changes in the Staphylococcus aureus transcriptome during early adaptation to the lung. PLoSOne 7: e41329.

Chagnot C, Zorgani MA, Astruc T, Desvaux M (2013) Proteinaceous determinants of surface colonization in bacteria: bacterial adhesion and biofilm formation from a protein secretion perspective. Front Microbiol 4: 303.

Chan PF, Foster SJ (1998) The role of environmental factors in the regulation of virulence-determinant expression in Staphylococcus aureus 8325-4. Microbiology 144: 2469-2479.

Clarke SR, Foster SJ (2006) Surface adhesins of Staphylococcus aureus. Adv Microb Physiol 51: 187-224.

Collins J, Rudkin J, Recker M, Pozzi C, O’Gara JP, Massey RC (2010) Offsetting virulence and antibiotic resistance costs by MRSA. ISMEJ 4: 577-584.

Cremieux AC, Dumitrescu O, Lina G, Vallee C, Cote JF, Muffat-Joly M, Lilin T, Etienne J, Vandenesch F, SalehMghir A (2009) Panton-valentine leukocidin enhances the severity of community-associated methicillin-resistant Staphylococcus aureus rabbit osteomyelitis. PLoSOne 4: e7204.

Daghighi S, Sjollema J, Dijkstra RJ, Jaspers V, Zaat SA, van der Mei HC, Busscher HJ (2014) Real-time quantification of matrix metalloproteinase and integrin alphavbeta3 expression during biomaterial-associated infection in a murine model. Eur Cell Mater 27: 26-37. 
Dalstrom DJ, Venkatarayappa I, Manternach AL, Palcic MS, Heyse BA, Prayson MJ (2008) Time-dependent contamination of opened sterile operating-room trays. J Bone Joint Surg Am 90: 1022-1025.

Dalton T, Dowd SE, Wolcott RD, Sun Y, Watters C, Griswold JA, Rumbaugh KP (2011) An in vivo polymicrobial biofilm wound infection model to study interspecies interactions. PLoSOne 6: e27317.

Darouiche R (2013)Antimicrobial-modified vascular catheters. In: Biomaterials Associated Infection (Moriarty TF, Zaat SAJ, Busscher HJ, eds), Springer New York, pp 485-503.

Deleo FR, Otto M, Kreiswirth BN, Chambers HF (2010) Community-associated meticillin-resistant Staphylococcus aureus. Lancet 375: 1557-1568.

Diep BA, Palazzolo-Ballance AM, Tattevin P, Basuino L, Braughton KR, Whitney AR, Chen L, Kreiswirth BN, Otto M, Deleo FR, Chambers HF (2008) Contribution of Panton-Valentine leukocidin in community-associated methicillin-resistant Staphylococcus aureus pathogenesis. PLoSOne 3: e3198.

Duan K, Dammel C, Stein J, Rabin H, Surette MG (2003) Modulation of Pseudomonas aeruginosa gene expression by host microflora through interspecies communication. Mol Microbiol 50: 1477-1491.

Ecker DJ, Sampath R, Massire C, Blyn LB, Hall TA, Eshoo MW, Hofstadler SA (2008) Ibis T5000: a universal biosensor approach for microbiology. Nat Rev Microbiol 6: $553-558$.

Elasri MO, Thomas JR, Skinner RA, Blevins JS, Beenken KE, Nelson CL, Smeltzer MS (2002) Staphylococcus aureus collagen adhesin contributes to the pathogenesis of osteomyelitis. Bone 30: 275-280.

Elek SD, Conen PE (1957) The virulence of Staphylococcus pyogenes for man; a study of the problems of wound infection. Br J Exp Pathol 38: 573-586.

Fazli M, Bjarnsholt T, Kirketerp-Moller K, Jorgensen B, Andersen AS, Krogfelt KA, Givskov M, Tolker-Nielsen T (2009) Nonrandom distribution of Pseudomonas aeruginosa and Staphylococcus aureus in chronic wounds. J Clin Microbiol 47: 4084-4089.

Fisher CJ, Jr., Agosti JM, Opal SM, Lowry SF, Balk RA, Sadoff JC, Abraham E, Schein RM, Benjamin E (1996) Treatment of septic shock with the tumor necrosis factor receptor:Fc fusion protein. The Soluble TNF Receptor Sepsis Study Group. N Engl J Med 334: 1697-1702.

Fitzgerald RH, Jr. (1979) Microbiologic environment of the conventional operating room. Arch Surg 114: 772-775.

Fluckiger U, Ulrich M, Steinhuber A, Doring G, Mack D, Landmann R, Goerke C, Wolz C (2005) Biofilm formation, icaADBC transcription, and polysaccharide intercellular adhesin synthesis by staphylococci in a device-related infection model. Infect Immun 73: 18111819.

Fowler VG, Allen KB, Moreira ED, Moustafa M, Isgro F, Boucher HW, Corey GR, Carmeli Y, Betts R, Hartzel JS, Chan IS, McNeely TB, Kartsonis NA, Guris D, Onorato MT, Smugar SS, DiNubile MJ, Sobanjo-ter Meulen A (2013) Effect of an investigational vaccine for preventing Staphylococcus aureus infections after cardiothoracic surgery: a randomized trial. JAMA 309: 1368-1378.
Fuchs T, Stange R, Schmidmaier G, Raschke MJ (2011) The use of gentamicin-coated nails in the tibia: preliminary results of a prospective study. Arch Orthop Trauma Surg 131: 1419-1425.

Garzoni C, Francois P, Huyghe A, Couzinet S, Tapparel C, Charbonnier Y, Renzoni A, Lucchini S, Lew DP, Vaudaux P, Kelley WL, Schrenzel J (2007) A global view of Staphylococcus aureus whole genome expression upon internalization in human epithelial cells. BMC Genomics 8: 171.

Gillet Y, Issartel B, Vanhems P, Fournet JC, Lina G, Bes M, Vandenesch F, Piemont Y, Brousse N, Floret D, Etienne J (2002) Association between Staphylococcus aureus strains carrying gene for Panton-Valentine leukocidin and highly lethal necrotising pneumonia in young immunocompetent patients. Lancet 359: 753-759.

Goerke C, Wolz C (2004) Regulatory and genomic plasticity of Staphylococcus aureus during persistent colonization and infection. Int J Med Microbiol 294: 195202.

Goerke C, Campana S, Bayer MG, Doring G, Botzenhart K, Wolz C (2000) Direct quantitative transcript analysis of the agr regulon of Staphylococcus aureus during human infection in comparison to the expression profile in vitro. Infect Immun 68: 1304-1311.

Goerke C, Fluckiger U, Steinhuber A, Zimmerli W, Wolz C (2001) Impact of the regulatory loci agr, sarA and sae of Staphylococcus aureus on the induction of alphatoxin during device-related infection resolved by direct quantitative transcript analysis. Mol Microbiol 40: 14391447.

Goerke C, Fluckiger U, Steinhuber A, Bisanzio V, Ulrich M, Bischoff M, Patti JM, Wolz C (2005) Role of Staphylococcus aureus global regulators sae and sigmaB in virulence gene expression during device-related infection. Infect Immun 73: 3415-3421.

Gottenbos B, van der Mei HC, Busscher HJ (1999) Models for studying initial adhesion and surface growth in biofilm formation on surfaces. Methods Enzymol 310: 523-534.

Grainger DW, van der Mei HC, Jutte PC, van den Dungen JJ, Schultz MJ, van der Laan BF, Zaat SA, Busscher HJ (2013) Critical factors in the translation of improved antimicrobial strategies for medical implants and devices. Biomaterials 34: 9237-9243.

Gristina AG, Naylor P, Myrvik Q (1988) Infections from biomaterials and implants: a race for the surface. Med Prog Technol 14: 205-224.

Gristina AG, Naylor PT, Myrvik QN (1991) Mechanisms of musculoskeletal sepsis. Orthop Clin North Am 22: 363 371 .

Guillou PJ (1993) Biological variation in the development of sepsis after surgery or trauma. Lancet $\mathbf{3 4 2}$ : 217-220.

Gustilo RB, Anderson JT (1976) Prevention of infection in the treatment of one thousand and twenty-five open fractures of long bones: retrospective and prospective analyses. J Bone Joint Surg Am 58: 453-458.

Haja MH, Corris PA, Nicholson A, Perry JD, Meachery G, Marrs EC, Peart S, Fagan C, Lordan JL, Fisher AJ, Gould FK (2012) Targeted antibiotic prophylaxis for lung 
transplantation in cystic fibrosis patients colonised with Pseudomonas aeruginosa using multiple combination bactericidal testing. J Transplant 2012: 135738.

Hanssen AD, Osmon DR, Nelson CL (1997) Prevention of deep periprosthetic joint infection. Instr Course Lect 46: 555-567.

Hardes J, Ahrens H, Gebert C, Streitbuerger A, Buerger H, Erren M, Gunsel A, Wedemeyer C, Saxler G, Winkelmann W, Gosheger G (2007) Lack of toxicological side-effects in silver-coated megaprostheses in humans. Biomaterials 28: 2869-2875.

Hendricks KJ, Burd TA, Anglen JO, Simpson AW, Christensen GD, Gainor BJ (2001) Synergy between Staphylococcus aureus and Pseudomonas aeruginosa in a rat model of complex orthopaedic wounds. J Bone Joint Surg Am 83-A: 855-861.

Hoch RC, Rodriguez R, Manning T, Bishop M, Mead P, Shoemaker WC, Abraham E (1993) Effects of accidental trauma on cytokine and endotoxin production. Crit Care Med 21: 839-845.

Høiby N, Bjarnsholt T, Givskov M, Molin S, Ciofu O (2010) Antibiotic resistance of bacterial biofilms. Int J Antimicrob Agents 35: 322-332.

Holtfreter S, Kolata J, Broker BM (2010) Towards the immune proteome of Staphylococcus aureus - The anti-S. aureus antibody response. Int J Med Microbiol 300: 176192.

Howard JL, Hanssen AD (2007) Principles of a clean operating room environment. J Arthroplasty 22: 6-11.

Howe TS, Erlich G, Koh JS, Ng AC, Costerton W (2013) A case of an atypical femoral fracture associated with bacterial biofilm - pathogen or bystander? Osteoporos Int 24: 1765-1766.

Hudson MC, Ramp WK, Frankenburg KP (1999) Staphylococcus aureus adhesion to bone matrix and bone-associated biomaterials. FEMS Microbiol Lett 173: 279-284.

James GA, Swogger E, Wolcott R, Pulcini E, Secor P, Sestrich J, Costerton JW, Stewart PS (2008) Biofilms in chronic wounds. Wound Repair Regen 16: 37-44.

James RC, MacLeod CJ (1961) Induction of staphylococcal infections in mice with small inocula introduced on sutures. Br J Exp Pathol 42: 266-277.

Kadurugamuwa JL, Sin L, Albert E, Yu J, Francis K, DeBoer M, Rubin M, Bellinger-Kawahara C, Parr TRJ Jr, Contag PR (2003) Direct continuous method for monitoring biofilm infection in a mouse model. Infect Immun 71: 882-890.

Kalicke T, Schlegel U, Printzen G, Schneider E, Muhr G, Arens S (2003) Influence of a standardized closed soft tissue trauma on resistance to local infection. An experimental study in rats. J Orthop Res 21: 373-378.

Kasemo B, Lausmaa J (1994) Material-tissue interfaces: the role of surface properties and processes. Environ Health Perspect 102 Suppl 5: 41-45.

Katsikogianni M, Missirlis YF (2004) Concise review of mechanisms of bacterial adhesion to biomaterials and of techniques used in estimating bacteria-material interactions. Eur Cell Mater 8: 37-57.
Keays T, Ferris W, Vandemheen KL, Chan F, Yeung SW, Mah TF, Ramotar K, Saginur R, Aaron SD (2009) A retrospective analysis of biofilm antibiotic susceptibility testing: a better predictor of clinical response in cystic fibrosis exacerbations. J Cyst Fibros 8: 122-127.

Kim A, Kuti JL, Nicolau DP (2009) Probability of pharmacodynamic target attainment with standard and prolonged-infusion antibiotic regimens for empiric therapy in adults with hospital-acquired pneumonia. Clin Ther 31: 2765-2778.

Kim KS, Anthony BF (1981) Importance of bacterial growth phase in determining minimal bactericidal concentrations of penicillin and methicillin. Antimicrob Agents Chemother 19: 1075-1077.

Kollef M (2013) Preventive strategies in VAP: Focus on silver-coated endotracheal tubes. In: Biomaterials Associated Infection (Moriarty TF, Zaat SAJ, Busscher HJ, eds), Springer New York, pp 531-555.

Korgaonkar A, Trivedi U, Rumbaugh KP, Whiteley M (2013) Community surveillance enhances Pseudomonas aeruginosa virulence during polymicrobial infection. Proc Natl Acad Sci USA 110: 1059-1064.

Krettek C (1998) [Fracture and soft tissue damage]. Chirurg 69: 684-700.

Kuijer R, Jansen EJ, Emans PJ, Bulstra SK, Riesle J, Pieper J, Grainger DW, Busscher HJ (2007) Assessing infection risk in implanted tissue-engineered devices. Biomaterials 28: 5148-5154.

Kuklin NA, Clark DJ, Secore S, Cook J, Cope LD, McNeely T, Noble L, Brown MJ, Zorman JK, Wang XM, Pancari G, Fan H, Isett K, Burgess B, Bryan J, Brownlow M, George H, Meinz M, Liddell ME, Kelly R, Schultz L, Montgomery D, Onishi J, Losada M, Martin M, Ebert T, Tan CY, Schofield TL, Nagy E, Meineke A, Joyce JG, Kurtz MB, Caulfield MJ, Jansen KU, McClements W, Anderson AS (2006) A novel Staphylococcus aureus vaccine: iron surface determinant B induces rapid antibody responses in rhesus macaques and specific increased survival in a murine $S$. aureus sepsis model. Infect Immun 74: 22152223.

Lammers A, Kruijt E, van de Kuijt C, Nuijten PJ, Smith HE (2000) Identification of Staphylococcus aureus genes expressed during growth in milk: a useful model for selection of genes important in bovine mastitis? Microbiology 146: 981-987.

Lina G, Piemont Y, Godail-Gamot F, Bes M, Peter MO, Gauduchon V, Vandenesch F, Etienne J (1999) Involvement of Panton-Valentine leukocidin-producing Staphylococcus aureus in primary skin infections and pneumonia. Clin Infect Dis 29: 1128-1132.

Lindsay JA, Holden MT (2006) Understanding the rise of the superbug: investigation of the evolution and genomic variation of Staphylococcus aureus. Funct Integr Genomics 6: 186-201.

Lipinska U, Hermans K, Meulemans L, Dumitrescu O, Badiou C, Duchateau L, Haesebrouck F, Etienne J, Lina G (2011) Panton-Valentine leukocidin does play a role in the early stage of Staphylococcus aureus skin infections: a rabbit model. PLoSOne 6: e22864. 
Livermore DM (2011) Discovery research: the scientific challenge of finding new antibiotics. J Antimicrob Chemother 66: 1941-1944.

Loffler B, Hussain M, Grundmeier M, Bruck M, Holzinger D, Varga G, Roth J, Kahl BC, Proctor RA, Peters G (2010) Staphylococcus aureus panton-valentine leukocidin is a very potent cytotoxic factor for human neutrophils. PLoS Pathog 6: e1000715.

Lynch RJ, Englesbe MJ, Sturm L, Bitar A, Budhiraj K, Kolla S, Polyachenko Y, Duck MG, Campbell DA, Jr. (2009) Measurement of foot traffic in the operating room: implications for infection control. Am J Med Qual 24: 45-52.

Massey RC, Dissanayeke SR, Cameron B, Ferguson D, Foster TJ, Peacock SJ (2002) Functional blocking of Staphylococcus aureus adhesins following growth in ex vivo media. Infect Immun 70: 5339-5345.

Mastropaolo MD, Evans NP, Byrnes MK, Stevens AM, Robertson JL, Melville SB (2005) Synergy in polymicrobial infections in a mouse model of type 2 diabetes. Infect Immun 73: 6055-6063.

Matsukawa M, Kunishima Y, Takahashi S, Takeyama K, Tsukamoto T (2005) Bacterial colonization on intraluminal surface of urethral catheter. Urology 65: 440-444.

McAleese FM, Walsh EJ, Sieprawska M, Potempa J, Foster TJ (2001) Loss of clumping factor B fibrinogen binding activity by Staphylococcus aureus involves cessation of transcription, shedding and cleavage by metalloprotease. J Biol Chem 276: 29969-29978.

Mohler KM, Torrance DS, Smith CA, Goodwin RG, Stremler KE, Fung VP, Madani H, Widmer MB (1993) Soluble tumor necrosis factor (TNF) receptors are effective therapeutic agents in lethal endotoxemia and function simultaneously as both TNF carriers and TNF antagonists. J Immunol 151: 1548-1561.

Molina-Manso D, del PG, Ortiz-Perez A, ManrubiaCobo M, Gomez-Barrena E, Cordero-Ampuero J, Esteban J (2013) In vitro susceptibility to antibiotics of staphylococci in biofilms isolated from orthopaedic infections. Int J Antimicrob Agents 41: 521-523.

Montanaro L, Campoccia D, Arciola CR (2008) Nanostructured materials for inhibition of bacterial adhesion in orthopedic implants: a minireview. Int J Artif Organs 31: 771-776.

Moriarty TF, Elborn JS, Tunney MM (2007) Effect of $\mathrm{pH}$ on the antimicrobial susceptibility of planktonic and biofilm-grown clinical Pseudomonas aeruginosa isolates. Br J Biomed Sci 64: 101-104.

Moriarty TF, Poulsson AHC, Rochford ETJ, Richards RG (2011) Bacterial adhesion and biomaterial surfaces. In: Comprehensive Biomaterials (Paul D, ed), Elsevier, Oxford, pp 75-100.

Moskowitz SM, Emerson JC, McNamara S, Shell RD, Orenstein DM, Rosenbluth D, Katz MF, Ahrens R, Hornick D, Joseph PM, Gibson RL, Aitken ML, Benton WW, Burns JL (2011) Randomized trial of biofilm testing to select antibiotics for cystic fibrosis airway infection. Pediatr Pulmonol 46: 184-192.

Neut D, Kluin OS, Thompson J, van der Mei HC, Busscher HJ (2010) Gentamicin release from commercially-available gentamicin-loaded PMMA bone cements in a prosthesis-related interfacial gap model and their antibacterial efficacy. BMC Musculoskelet Disord 11: 258 .

Norden CW (1970) Experimental osteomyelitis. I. A description of the model. J Infect Dis 122: 410-418.

Oliver JD (2010) Recent findings on the viable but nonculturable state in pathogenic bacteria. FEMS Microbiol Rev 34: 415-425.

Otto M (2010) Basis of virulence in communityassociated methicillin-resistant Staphylococcus aureus. Annu Rev Microbiol 64: 143-162.

Palmer M, Costerton W, Sewecke J, Altman D (2011) Molecular techniques to detect biofilm bacteria in long bone nonunion: a case report. Clin Orthop Relat Res 469: 3037-3042.

Panahi P, Stroh M, Casper DS, Parvizi J, Austin MS (2012) Operating room traffic is a major concern during total joint arthroplasty. Clin Orthop Relat Res 470: 26902694.

Perl TM, Cullen JJ, Wenzel RP, Zimmerman MB, Pfaller MA, Sheppard D, Twombley J, French PP, Herwaldt LA (2002) Intranasal mupirocin to prevent postoperative Staphylococcus aureus infections. N Engl J Med 346: 1871-1877.

Peters BM, Jabra-Rizk MA, O’May GA, Costerton JW, Shirtliff ME (2012) Polymicrobial interactions: impact on pathogenesis and human disease. Clin Microbiol Rev 25: 193-213.

Pittet D, Simon A, Hugonnet S, Pessoa-Silva CL, Sauvan V, Perneger TV (2004) Hand hygiene among physicians: performance, beliefs, and perceptions. Ann Intern Med 141: 1-8.

Poelstra KA, Barekzi NA, Slunt JB, Schuler TC, Grainger DW (2000) Surgical irrigation with pooled human immunoglobulin $\mathrm{G}$ to reduce post-operative spinal implant infection. Tissue Eng 6: 401-411.

Poelstra KA, Barekzi NA, Rediske AM, Felts AG, Slunt JB, Grainger DW (2002) Prophylactic treatment of grampositive and gram-negative abdominal implant infections using locally delivered polyclonal antibodies. J Biomed Mater Res 60: 206-215.

Pribaz JR, Bernthal NM, Billi F, Cho JS, Ramos RI, Guo Y, Cheung AL, Francis KP, Miller LS (2012) Mouse model of chronic post-arthroplasty infection: noninvasive in vivo bioluminescence imaging to monitor bacterial burden for long-term study. J Orthop Res 30: 335-340.

Proctor RA (2012) Is there a future for a Staphylococcus aureus vaccine? Vaccine 30: 2921-2927.

Que YA, Haefliger JA, Piroth L, Francois P, Widmer E, Entenza JM, Sinha B, Herrmann M, Francioli P, Vaudaux P, Moreillon P (2005) Fibrinogen and fibronectin binding cooperate for valve infection and invasion in Staphylococcus aureus experimental endocarditis. J Exp Med 201: 1627-1635.

Ramos ER, Reitzel R, Jiang Y, Hachem RY, Chaftari AM, Chemaly RF, Hackett B, Pravinkumar SE, Nates J, Tarrand JJ, Raad II (2011) Clinical effectiveness and risk of emerging resistance associated with prolonged use of antibiotic-impregnated catheters: more than 0.5 million catheter days and 7 years of clinical experience. Crit Care Med 39: 245-251. 
Rogasch K, Ruhmling V, Pane-Farre J, Hoper D, Weinberg C, Fuchs S, Schmudde M, Broker BM, Wolz C, Hecker M, Engelmann S (2006) Influence of the twocomponent system SaeRS on global gene expression in two different Staphylococcus aureus strains. J Bacteriol 188: 7742-7758.

Rooijakkers SH, van Kessel KP, van Strijp JA (2005) Staphylococcal innate immune evasion. Trends Microbiol 13: 596-601.

Rudkin JK, Edwards AM, Bowden MG, Brown EL, Pozzi C, Waters EM, Chan WC, Williams P, O'Gara JP, Massey RC (2012) Methicillin resistance reduces the virulence of healthcare-associated methicillin-resistant Staphylococcus aureus by interfering with the agr quorum sensing system. J Infect Dis 205: 798-806.

Schafer P, Fink B, Sandow D, Margull A, Berger I, Frommelt L (2008) Prolonged bacterial culture to identify late periprosthetic joint infection: a promising strategy. Clin Infect Dis 47: 1403-1409.

Scheman L, Janota M, Lewin P (1941) The Production of Experimental Osteomyelitis. JAMA 117: 1525-1529.

Scully IL, Liberator PA, Jansen KU, Anderson AS (2014) Covering all the bases: Preclinical development of an effective vaccine. Front Immunol 5: 109.

Sellman BR, Timofeyeva Y, Nanra J, Scott A, Fulginiti JP, Matsuka YV, Baker SM (2008) Expression of Staphylococcus epidermidis SdrG increases following exposure to an in vivo environment. Infect Immun $\mathbf{7 6}$ : 2950-2957.

Sepandj F, Ceri H, Gibb A, Read R, Olson M (2004) Minimum inhibitory concentration (MIC) versus minimum biofilm eliminating concentration (MBEC) in evaluation of antibiotic sensitivity of gram-negative bacilli causing peritonitis. Perit Dial Int 24: 65-67.

Sjollema J, Sharma PK, Dijkstra RJ, van Dam GM, van der Mei HC, Engelsman AF, Busscher HJ (2010) The potential for bio-optical imaging of biomaterial-associated infection in vivo. Biomaterials 31: 1984-1995.

Smith AL, Fiel SB, Mayer-Hamblett N, Ramsey B, Burns JL (2003) Susceptibility testing of Pseudomonas aeruginosa isolates and clinical response to parenteral antibiotic administration: lack of association in cystic fibrosis. Chest 123: 1495-1502.

Stone PW, Larson E, Kawar LN (2002) A systematic audit of economic evidence linking nosocomial infections and infection control interventions: 1990-2000. Am J Infect Control 30: 145-152.

Stone PW, Glied SA, McNair PD, Matthes N, Cohen B, Landers TF, Larson EL (2010) CMS changes in reimbursement for HAIs: setting a research agenda. Med Care 48: 433-439.

Subbiahdoss G, Kuijer R, Grijpma DW, van der Mei HC, Busscher HJ (2009) Microbial biofilm growth vs. tissue integration: "the race for the surface" experimentally studied. Acta Biomater 5: 1399-1404.

Subbiahdoss G, Grijpma DW, van der Mei HC, Busscher HJ, Kuijer R (2010a) Microbial biofilm growth versus tissue integration on biomaterials with different wettabilities and a polymer-brush coating. J Biomed Mater Res A 94: 533-538.
Subbiahdoss G, Pidhatika B, Coullerez G, Charnley M, Kuijer R, van der Mei HC, Textor M, Busscher HJ (2010b) Bacterial biofilm formation versus mammalian cell growth on titanium-based mono- and bi-functional coating. Eur Cell Mater 19: 205-213.

Subbiahdoss G, Fernandez IC, Domingues JF, Kuijer R, van der Mei HC, Busscher HJ (2011) In vitro interactions between bacteria, osteoblast-like cells and macrophages in the pathogenesis of biomaterial-associated infections. PLoSOne 6: e24827.

Sun Y, Dowd SE, Smith E, Rhoads DD, Wolcott RD (2008) In vitro multispecies Lubbock chronic wound biofilm model. Wound Repair Regen 16: 805-813.

Trampuz A, Widmer AF (2004) Hand hygiene: a frequently missed lifesaving opportunity during patient care. Mayo Clin Proc 79: 109-116.

Trampuz A, Piper KE, Jacobson MJ, Hanssen AD, Unni KK, Osmon DR, Mandrekar JN, Cockerill FR, Steckelberg JM, Greenleaf JF, Patel R (2007) Sonication of removed hip and knee prostheses for diagnosis of infection. N Engl J Med 357: 654-663.

Tunney MM, Patrick S, Curran MD, Ramage G, Hanna D, Nixon JR, Gorman SP, Davis RI, Anderson N (1999) Detection of prosthetic hip infection at revision arthroplasty by immunofluorescence microscopy and PCR amplification of the bacterial 16S rRNA gene. J Clin Microbiol 37: 3281-3290.

Uckay I, Harbarth S, Peter R, Lew D, Hoffmeyer P, Pittet D (2010) Preventing surgical site infections. Expert Rev Anti Infect Ther 8: 657-670.

Uckay I, Hoffmeyer P, Lew D, Pittet D (2013) Prevention of surgical site infections in orthopaedic surgery and bone trauma: state-of-the-art update. J Hosp Infect 84: $5-12$.

Van Oosten M, Schafer T, Gazendam JA, Ohlsen K, Tsompanidou E, de Goffau MC, Harmsen HJ, Crane LM, Lim E, Francis KP, Cheung L, Olive M, Ntziachristos V, van Dijl JM, van Dam GM (2013) Real-time in vivo imaging of invasive- and biomaterial-associated bacterial infections using fluorescently labelled vancomycin. Nat Commun 4: 2584.

Von Eiff C, Becker K, Machka K, Stammer H, Peters G (2001) Nasal carriage as a source of Staphylococcus aureus bacteremia. Study Group. N Engl J Med 344: 11-16.

Voyich JM, Otto M, Mathema B, Braughton KR, Whitney AR, Welty D, Long RD, Dorward DW, Gardner DJ, Lina G, Kreiswirth BN, Deleo FR (2006) Is PantonValentine leukocidin the major virulence determinant in community-associated methicillin-resistant Staphylococcus aureus disease? J Infect Dis 194: 1761-1770.

Vriesema AJ, Beekhuizen H, Hamdi M, Soufan A, Lammers A, Willekens B, Bakker O, Welten AG, Veltrop MH, van De Gevel JS, Dankert J, Zaat SA (2000) Altered gene expression in Staphylococcus aureus upon interaction with human endothelial cells. Infect Immun 68: 1765-1772.

Wichmann MW, Zellweger R, DeMaso CM, Ayala A, Williams C, Chaudry IH (1996) Immune function is more compromised after closed bone fracture and hemorrhagic shock than hemorrhage alone. Arch Surg 131: 995-1000.

Widmer AF, Frei R, Rajacic Z, Zimmerli W (1990) Correlation between in vivo and in vitro efficacy of 
antimicrobial agents against foreign body infections. J Infect Dis 162: 96-102.

Wiltshire MD, Foster SJ (2001) Identification and analysis of Staphylococcus aureus components expressed by a model system of growth in serum. Infect Immun 69: 5198-5202.

Xiong YQ, Willard J, Yeaman MR, Cheung AL, Bayer AS (2006) Regulation of Staphylococcus aureus alphatoxin gene (hla) expression by agr, sarA, and sae in vitro and in experimental infective endocarditis. J Infect Dis 194: 1267-1275.

Yarwood JM, McCormick JK, Paustian ML, Kapur V, Schlievert PM (2002) Repression of the Staphylococcus aureus accessory gene regulator in serum and in vivo. J Bacteriol 184: 1095-1101.

Zimmerli W, Waldvogel FA, Vaudaux P, Nydegger UE (1982) Pathogenesis of foreign body infection: description and characteristics of an animal model. J Infect Dis 146: 487-497.

\section{Discussion with Reviewers}

J. Wenke: The authors suggest changes in in vitro and pre-clinical testing to survive regulatory scrutiny. Authors state that consensus is needed on how to do the required tests. How do the authors envisage that such consensus will be reached, and more importantly, convince the scientific (and regulatory) community of this?

Authors: Guideline documents are available for numerous clinical and basic laboratory assays. The bodies publishing such guidelines, such as the Clinical and Laboratory
Standards Institute (CLSI), and the International Organization for Standardization (ISO) draw upon the expertise available within the practicing professionals in the field. Recently, a consensus document has been published on the diagnosis of prosthetic joint infection, again published with the input of professionals active in the field. A similar process could clearly be suitable for generating and publicising preferred protocols in the area of anti-infective device preclinical testing.

H.C. van der Mei: Hardware infections are both fairly common and very challenging to treat, and it is clear that the current in vitro and in vivo assessments may not be the most predictive of clinical efficacy. There are many different variations for anti-infection hardware for different clinical issues, which would likely require different preclinical assessment approaches. What approach would you suggest for preclinical evaluation of an intramedullary nail that has a durable coating that slowly elutes an antimicrobial? Please assume that the application is for open fractures of the tibial diaphysis.

Authors: The development of such a device has precedence in the European market with the development of the ETN ProTect antimicrobial tibial nail by DePuy Synthes. The preclinical testing of this device has been published in the literature, with several studies establishing the efficacy of the coating in preventing infection in preclinical in vivo models. The ETN ProTect nail provides a good example of a product tested in a rat model, which revealed a $100 \%$ reduction in bacterial numbers. As such, this model represents a positive example of a preclinical test phase accurately predicting clinical success, as seen by published data since its release for human medicine. 